\title{
Pengaruh Model Pembelajaran Kooperatif Tipe Numbered HEAD TOGETHER TERHADAP KEMAMPUAN KOMUNIKASI MATEMATIS
}

\author{
Deutelina S. Lagur ${ }^{1}$, Alberta P. Makur ${ }^{2}$, dan Apolonia H. Ramda ${ }^{3}$ \\ 1Program Studi Pendidikan Matematika, STKIP Santu Paulus \\ Jl. Ahmad Yani no 10, Ruteng, 86511, Indonesia \\ densylagur@gmail.com \\ ${ }^{2}$ Program Studi Pendidikan Matematika, STKIP Santu Paulus \\ Jl. Ahmad Yani no 10, Ruteng, 86511, Indonesia \\ alberta.makur@gmail.com \\ ${ }^{3}$ Program Studi Pendidikan Matematika, STKIP Santu Paulus \\ Jl. Ahmad Yani no 10, Ruteng, 86511, Indonesia \\ apoloniahendrice@gmail.com
}

Artikel diterima: 6 Agustus 2018, direvisi: 9 September 2018, diterbitkan: 30 September 2018

\begin{abstract}
Abstrak
Tujuan penelitian ini adalah untuk mengetahui perbedaan kemampuan komunikasi matematis siswa kelas X SMK Santo Aloisius Ruteng tahun ajaran 2017/2018 yang diajarkan dengan menggunakan model pembelajaran kooperatif tipe NHT dibandingkan dengan yang diajarkan dengan model pembelajaran langsung. Penelitian ini merupakan penelitian eksperimen dengan desain penelitian posttest only control group design. Populasi dalam penelitian ini adalah seluruh siswa kelas X jurusan Teknik Kendaraan Ringan (TKR) SMK Santo Aloisius Ruteng yang tersebar dalam tiga kelas. Dua kelas dipilih secara acak untuk dijadikan sampel penelitian. Kelas X TKR B terpilih sebagai kelas eksperimen yang diajarkan dengan menerapkan model pembelajaran kooperatif tipe NHT sedangkan kelas X TKR C diajarkan dengan model pembelajaran langsung. Data yang diperoleh dalam penelitian ini berupa skor kemampuan komunikasi matematis siswa yang dianalisis dengan uji t. Berdasarkan hasil analisis data diperoleh bahwa kemampuan komunikasi matematis siswa yang menggunakan model pembelajaran kooperatif tipe NHT lebih tinggi dibandingkan dengan kemampuan komunikasi matematis siswa yang menggunakan model pembelajaran langsung.

Kata Kunci: Model Pembelajaran Kooperatif Tipe NHT, Model Pembelajaran Langsung, Kemampuan Komunikasi Matematis.
\end{abstract}

\begin{abstract}
Effect Of Cooperative Learning Model Of Numbered Head Together Type On Mathematical Communication Ability)

This study was aimed to determine the effect of cooperative learning model NHT type towards students' mathematical communication skill of grade X SMK Santo Aloisius Ruteng in academic year 2017/2018. This study was experimental research with post-test only control group design. The population of this study was all the tenth-grade students majoring in Teknik Kendaraan Ringan (TKR). X TKR B selected as an experimental class taught by applying cooperative learning type NHT while $X$ TKR C taught by direct learning model. The data obtained was analyzed by $t$ test. Analysis data result obtained that students' mathematical communication skill that using cooperative learning type NHT is higher than students' mathematical communication skill that using direct learning model.

Keyword: Cooperative Learning Type NHT, Direct Learning Model, Mathematical Communication Skils.
\end{abstract}




\section{Pendahuluan}

Komunikasi merupakan hal yang sangat penting dalam kehidupan. Tanpa komunikasi, manusia sulit berhubungan satu sama lain. Di sekolah, komunikasi memungkinkan siswa menyampaikan pendapat, gagasan, pokok pikiran serta tanggapannya tidak hanya pada guru namun juga teman sebaya, kelompok maupun seluruh kelas dalam kegiatan pembelajaran. Permendiknas No 22 tahun 2006 menjelaskan salah satu target dalam pembelajaran matematika adalah tumbuhnya kemampuan siswa dalam mengkomunikasikan ide atau pokok pikiran dalam bentuk simbol, tabel, diagram, atau media lain untuk menggambarkan keadaan atau masalah (Depdiknas, 2006: 146).

Kemampuan komunikasi matematis merupakan salah satu proses penting dalam pembelajaran matematika. Komunikasi menjadi salah satu fokus dalam pembelajaran matematika karena pada hakikatnya matematika adalah bahasa (Husna, Fatimah, 2013; Luritawaty, 2016; Sritresna, 2017; Alamiah \& Afriansyah, 2018). Matematika bukan hanya sebagai sarana berpikir yang membantu siswa untuk menemukan pola, memecahkan masalah, dan menarik kesimpulan, tetapi lebih dari itu matematika berfungsi sebagai alat untuk mengkomunikasikan pikiran siswa tentang ide dengan jelas, tepat, dan ringkas. Hal senada juga dikemukakan Suryadi (2009: 171) bahwa sebagai bahasa,, matematika menggunakan istilah serta simbol-simbol yang didefinisikan secara tepat. Selain itu, pembelajaran matematika merupakan kegiatan interaksi antara guru dan murid.

Rendahnya kemampuan komunikasi matematis siswa juga terjadi di SMK Santo Aloisius Ruteng tempat peneliti melaksanakan kegiatan Praktik Pengalaman Lapangan (PPL). Berdasarkan observasi selama kegiatan PPL oleh peneliti dan wawancara tidak terstruktur dengan guru mata pelajaran matematika SMK Santo Aloisius Ruteng, ditemukan masalah yang berkaitan dengan belum optimalnya usaha meningkatkan kemampuan komunikasi matematis siswa. Para siswa masih kesulitan dalam menjelaskan ide matematisnya secara lisan maupun tertulis, kesulitan dalam membuat model matematika dari masalah kontekstual, menjelaskan kembali materi yang telah diperoleh, maupun menjawab pertanyaan yang diajukan guru.

Hal ini terlihat pada saat siswa diberikan soal cerita yang berkaitan dengan materi Sistem Persamaan Linear Dua Variabel (SPLDV). Para siswa rata-rata masih kesulitan dalam membuat model matematika dari masalah tersebut, terutama bila soal yang harus diselesaikan berbeda dari contoh yang diberikan guru. Selain itu, siswa pasif pada saat diminta untuk menjelaskan penyelesaian soal di papan tulis, menjawab pertanyaan yang diajukan guru, maupun ketika diberi kesempatan untuk bertanya mengenai materi yang telah dipelajari. 
Rendahnya kemampuan komunikasi matematis siswa dapat disebabkan oleh berbagai faktor, salah satunya penerapan model pembelajaran yang kurang memberi ruang bagi siswa mengembangkan kemampuan komunikasi matematisnya. Ini terjadi karena sistem pendidikan di sekolah Indonesia pada umumnya menargetkan agar kemampuan matematika siswa mencapai level rata-rata (Makur, Prahmana, dan Gunur, 2018). Model pembelajaran yang diterapkan di sekolah saat ini adalah model pembelajaran langsung, di mana guru cenderung menggunakan metode ceramah dalam proses pembelajaran. Shoimin (2014: 67) mengemukakan bahwa dalam model pembelajaran langsung, guru memainkan peranan pusat. Akibatnya, siswa kurang diberi ruang untuk terlibat aktif dalam proses pembelajaran, sehingga turut mempengaruhi kemampuan komunikasi matematisnya.

Pantaleon (2011:53) mengemukakan salah satu peran guru dalam proses pembelajaran adalah bagaimana membelajarkan subjek didik agar semua aspek dalam diri siswa dapat bertumbuh dan berkembang secara seimbang. Dalam hal ini, guru memiliki peran penting dalam merancang model pembelajaran yang dapat menimbulkan partisiasi aktif siswa dalam pembelajaran. Untuk itu diperlukan suatu model pembelajaran yang dapat meningkatkan kemampuan komunikasi matematis siswa (Pantaleon, 2011; Nendi, Mandur \& Makur, 2018).
Salah satu model pembelajaran yang dapat diterapkan adalah model pembelajaran kooperatif tipe Numbered Head Together (NHT). Tamur (2012: 105) mengemukakan penerapan model pembelajaran kooperatif dapat meningkatkan kemampuan komunikasi matematis siswa. Demikian pula Pratiwi (2010: 85) mengemukakan dengan menerapkan model pembelajaran kooperatif tipe NHT meningkatkan komunikasi matematis siswa.

Shoimin (2014:108) mengemukakan model pembelajaran kooperatif tipe NHT merupakan suatu model pembelajaran berkelompok yang setiap anggota kelompoknya bertanggung jawab atas tugas kelompoknya, sehingga tidak ada pemisahan antara siswa yang satu dengan siswa yang lain dalam satu kelompok untuk saling memberi dan menerima antara satu dengan yang lainnya. Dalam model pembelajaran ini, setiap siswa dalam kelompok mewakili nomor yang berbeda-beda dan secara bersama-sama mendiskusikan soal yang diberikan guru. Kemudian guru memanggil nomor tertentu dan siswa dari setiap kelompok yang mewakili nomor tersebut mengemukakan hasil diskusi kelompoknya.

Dengan adanya diskusi, para siswa tentunya saling mengkomunikasikan ide matematisnya dalam kelompok secara lisan. Hasil diskusi tersebut dituangkan secara tertulis dalam lembar jawaban kelompok. Selain itu, pada saat siswa melaporkan hasil diskusi kelompok, siswa yang nomornya dipanggil 359 
http://journal.institutpendidikan.ac.id/index.php/mosharafa

mengkomunikasikan ide matematisnya kepada guru dan siswa yang lain. Dengan demikian, model pembelajaran kooperatif tipe NHT menunjang aspek komunikasi siswa.

Berbeda dengan pembelajaran langsung, siswa menerima pelajaran dari guru dan guru menjadi pusat dalam proses pembelajaran. Guru secara aktif menyampaikan materi secara urut dari awal hingga akhir pelajaran. Siswa kurang dilibatkan secara aktif karena dalam hal ini siswa hanya menerima apa yang disampaikan oleh guru.

Dua model pembelajaran yang berbeda ini juga memberi hasil yang berbeda pada kemampuan siswa, dalam hal ini kemampuan komunikasi matematis. Karena itu peneliti tertarik untuk meneliti lebih lanjut mengenai perbedaaan kemampuan komunikasi matematis siswa yang diajarkan dengan model pembelajaran kooperatif tipe NHT dengan yang diajarkan dengan model pembelajaran langsung, sehingga peneliti melakukan penelitian dengan judul "Pengaruh Penggunaan Model Pembelajaran Kooperatif Tipe Numbered Head Together (NHT) Terhadap Kemampuan Komunikasi Matematis Siswa Kelas X SMK Santo Aloisius Ruteng Tahun Ajaran 2017/ 2018".

\section{Metode}

Penelitian ini merupakan penelitian eksperimen dengan desain penelitian posttest only control group design. Penelitian ini dilakukan untuk melihat 360 apakah kemampuan komunikasi matematis siswa kelas X SMK Santo Aloisius Ruteng tahun ajaran 2017/2018 yang diajarkan dengan model pembelajaran kooperatif tipe NHT lebih tinggi dibandingkan dengan kemampuan komunikasi matematis siswa yang diajarkan dengan model pembelajaran langsung. Dalam penelitian ini dipilih dua kelas secara acak. Kelas pertama sebagai kelas eksperimen sedangkan kelas kedua sebagai kelas kontrol. Kelas eksperimen diberi perlakuan berupa kegiatan pembelajaran dengan menggunakan model pembelajaran kooperatif tipe Numbered Head Together (NHT) sedangkan kelas kontrol menggunakan model pembelajaran langsung. Setelah dilaksanakan proses pembelajaran, dilakukan posttest untuk melihat apakah terdapat perbedaan kemampuan komunikasi matematis siswa kelas eksperimen dan kelas kontrol.

Penelitian ini dilaksanakan di SMK Santo Aloisius Ruteng pada semester genap tahun ajaran 2017/ 2018. Populasi penelitian adalah seluruh siswa kelas $X$ jurusan Teknik Kendaraan Ringan (TKR) yang tersebar dalam tiga kelas. Untuk keperluan penelitian dipilih dua kelas secara acak, yang terlebih dahulu diuji kesetaraannya dengan uji t.

Kelas-kelas yang setara dapat dijadikan sebagai kelas penelitian, dan dikatakan setara jika thitung < ttabel. 
Tabel 1

Uji Kesetaraan Kelas

\begin{tabular}{llll}
\hline Kelas & $t_{\text {hitung }}$ & $t_{\text {tabel }}$ & Kesimpulan \\
\hline$A B$ & 1.5169 & 3.3825 & Setara \\
\hline$A C$ & 0.8080 & 1.6923 & Setara \\
\hline$B C$ & 0.5765 & 1.6679 & Setara
\end{tabular}

Berdasarkan tabel 1, diperoleh bahwa ketiga kelas setara. Dari ketiga kelas ini dipilih dua kelas secara acak, dengan satu kelas sebagai kelas eksperimen dan satu kelas sebagai kelas kontrol. Berdasarkan hasil acak kelas yang dilakukan peneliti, kelas X TKR B yang berjumlah 30 siswa terpilih sebagai kelas ekperimen sedangkan kelas $X$ TKR $C$ yang berjumlah 29 siswa sebagai kelas kontrol.

Teknik pengumpulan data yang digunakan dalam penelitian adalah tes berupa posttest yang dilaksanakan setelah proses pembelajaran sehingga instrumennya berupa soal uraian berjumlah 5 butir. Sebelum dapat digunakan sebagai alat pengumpul data, terlebih dahulu dilakukan pengujian validitas dan reliabilitas butir soal. Oleh karena soal tes berupa uraian maka pengujian validitas menggunakan rumus korelasi product moment.

\section{Hasil dan Pembahasan}

Penelitian pada kelas eksperimen dilaksanakan dalam 7 pertemuan, dengan 6 pertemuan untuk kegiatan pembelajaran dan 1 pertemuan untuk posttest. Pada kegiatan inti pembelajaran, peneliti menerapkan model pembelajaran kooperatif tipe NHT dengan langkahlangkah sebagai berikut:
1. Penomoran

Peneliti membagi siswa dalam kelompok heterogen yang terdiri atas 4-5 siswa. Pembagian kelompok didasarkan atas kemampuan siswa, dengan setiap kelompok masing-masing memiliki anggota dengan kemampuan yang bervariasi. Hal ini bertujuan agar siswa dapat saling mengisi dalam menyelesaikan tugas yang diberikan. Siswa dalam setiap kelompok kemudian diberi nomor secara acak dari 1-5 sesuai dengan jumlah anggota.

2. Pemberian Tugas

Peneliti memberikan tugas kepada setiap kelompok berupa Lembar Kerja Siswa (LKS). Siswa diarahkan mengamati petunjukyang terdapat dalam LKS.

3. Diskusi

Siswa berdiskusi dalam kelompoknya masing-masing untuk menyelesaikan tugas yang diberikan. Setiap kelompok memastikan anggotanyadapat menyelesaikan tugas dalam bentuk soalsoal yang diberikan. Dalam hal ini, peneliti berperan sebagai fasilitator apabila ada kelompok mengalami kesulitan. Peneliti dapat membantu siswa dengan cara mengarahkan siswa untuk menyelesaikan masalah tanpa memberi tahu siswa jawaban atas masalah yang diberikan.

4. Menjawab

Setelah setiap kelompok selesai berdiskusi, peneliti memanggil nomor tertentu secara acak dan siswa dari setiap kelompok yang nomornya dipanggil mengacungkan tangan kemudian berdiri. Salah seorang siswa ditunjuk untuk 
melaporkan hasil kerja kelompoknya, sedangkan siswa dari kelompok lain dengan nomor yang sama menanggapi. Setelah itu beralih ke nomor soal selanjutnya, sementara peneliti memanggil nomor lain untuk menjadi perwakilan kelompok. begitu seterusnya sampai semua soal telah selesai dibahas.

5. Kesimpulan

Peneliti mengarahkan siswa membuat kesimpulan dari materi yang telah dipelajari.

Dalam penerapannya terutama pada pertemuan-pertemuan awal, kelompok diskusi sangat membutuhkan bimbingan karena sebelumnya terbiasa dengan model pembelajaran langsung. Para siswa aktif bertanya saat sesi diskusi karena materi yang didiskusikan belum diajarkan sebelumnya. Para siswa saling membagikan ide matematisnya untuk menyelesaikan tugas yang diberikan secara lisan kemudian menuangkannya secara tertulis pada LKS.

Dalam fase presentasi, siswa belum mengetahui siapa yang akan menjadi wakil dalam kelompok sehingga pada saat berdiskusi setiap siswa perlu menyiapkan diri dengan berusaha mengetahui dan memahami jawaban kelompoknya masingmasing. Hal ini menumbuhkan tanggung jawab individu untuk mencapai tujuan kelompok. Siswa yang terpilih untuk menjadi wakil kelompok mempresentasikan hasil diskusi kemudian ditanggapi oleh kelompok yang lain dengan nomor yang sama. Dalam fase ini terjadi interaksi antar kelompok melalui siswa yang nomornya dipanggil. Hal ini menunjang aspek komunikasi dalam diri siswa.

Adanya proses komunikasi matematis dalam diri siswa terutama terjadi dalam fase diskusi dan presentasi. Para siswa mendiskusikan jawaban kelompok dan aktif bertanya, karena materi yang didiskusikan belum diajarkan sebelumnya. Lalu, pada saat presentasi siswa yang nomornya terpilih mempertanggungjawabkan hasil diskusi kelompok kepada guru dan teman-teman kelas. Pada fase ini anggota lain dari kelompok yang melakukan presentasi tidak boleh memberikan bantuan dalam bentuk apapun kepada siswa yang terpilih. Demikian pula saat ada tanggapan dari kelompok lain dengan nomor yang sama. Hal ini bertujuan untuk menumbuhkan tanggung jawab individu dalam diri siswa, sekaligus mengasah kemampuan komunikasi matematisnya.

Tidak adanya bantuan dari sesama teman kelompok saat presentasi membuat siswa yang mewakili kelompok berusaha menjelaskan dengan baik. Peneliti lebih dominan memilih siswa yang cukup pasif untuk menjadi wakil kelompok dalam presentasi dengan tujuan mengasah kemampuan komunikasinya. Meskipun beberapa siswa masih kesulitan, namun adanya tanggung jawab sebagai utusan kelompok membuat mereka berusaha maksimal, karena keberhasilan maupun kegagalan seorang siswa berlaku untuk kelompok yang diwakilinya. 
Dalam penelitian ini, kemampuan komunikasi yang diukur adalah kemampuan komunikasi matematis secara tertulis. Meskipun dalam penerapannya kemampuan komunikasi yang lebih dominan dalam model pembelajaran kooperatif tipe NHT adalah kemampuan komunikasi secara lisan, namun peneliti berasumsi bahwa ada kaitan yang erat antara komunikasi secara lisan dan tertulis. Artinya, siswa menuliskan apa yang mereka diskusikan dan siswa yang mewakili dapat mempresentasikan dengan baik apabila memahami apa yang tertulis pada lembar jawaban. Dengan kata lain, kedua kemampuan komunikasi ini saling mempengaruhi satu sama lain.

Sementara itu pada kelas kontrol dilaksanakan dalam 6 pertemuan, yakni 5 pertemuan untuk proses pembelajaran dan 1 pertemuan untuk posttest. Peneliti menerapkan model pembelajaran langsung dengan langkah-langkah sebagai berikut: menyampaikan tujuan pembelajaran, menyajikan materi, memberikan latihan terbimbing, mengecek pemahaman siswa memberikan umpan balik, serta latihan mandiri. Dalam model pembelajaran langsung guru lebih aktif dalam proses pembelajaran, sementara siswa mendengarkan penjelasan guru dan menyelesaikan soal latihan. Siswa pasif karena menerima semua informasi dari guru. Hal ini menghilangkan tanggung jawab dalam diri siswa.

Setelah kegiatan pembelajaran dilaksanakan di kedua kelas, selanjutnya dilakukan posttest untuk mengukur kemampuan komunikasi matematis siswa. Instrumen tes berupa soal uraian. Sebelum digunakan, instrumen tes berjumlah 7 nomor diujikan pada kelas yang telah mempelajari materi untuk mengukur validitas dan reliabilitas instrumen. Validitas instrumen dihitung dengan rumus korelasi produk moment dengan kriteria berikut: valid apabila $\mathbf{r}_{\text {hitung }} \geq$ $r_{\text {tabel }}$ dan dinyatakan tidak valid apabila $\mathrm{r}_{\text {hitung }}<\mathrm{r}_{\text {tabel }}$ pada taraf signifikan 5\%. Selanjutnya butir soal yang valid diuji reliabilitasnya menggunakan rumus Alpha Cronbach. Instrumen dapat digunakan sebagai alat pengumpul data apabila hasil perhitungan reliabilitasnya berada pada klasifikasi tinggi dan sangat tinggi. Berdasarkan uji validitas, diperoleh $r_{\text {hitung }}$ dari setiap butir soal lebih tinggi dari $r_{\text {tabel }}$ sehingga ketujuh butir soal tersebut valid. Selanjutnya berdasarkan uji reliabilitas diperoleh $r_{11}=0.63$ yang berada pada kategori tinggi.

Dari ketujuh soal uji coba, diambil 5 butir soal untuk dijadikan soal posttest.

Tabel 2.

Nilai Posttest Kelas Eksperimen dan Kontrol

\begin{tabular}{|lll|}
\hline Statistik & $\begin{array}{l}\text { Kelas } \\
\text { Eksperimen }\end{array}$ & $\begin{array}{l}\text { Kelas } \\
\text { Kontrol }\end{array}$ \\
\hline Jumlah siswa $(\mathrm{n})$ & 30 & 29 \\
\hline Rataan $(\bar{X})$ & 73.10 & 60.47 \\
\hline Nilai maksimum $\left(X_{\max }\right)$ & 92.86 & 85.71 \\
\hline Nilai minimum $\left(X_{\min }\right)$ & 53.57 & 42.86 \\
\hline Varians $\left(s^{2}\right)$ & 115.03 & 143.89 \\
\hline Standar deviasi $(s)$ & 10.73 & 11.99 \\
\hline
\end{tabular}

Berdasarkan tabel II, skor kemampuan komunikasi matematis siswa pada kelas 
eksperimen lebih tinggi dibandingkan dengan kelas kontrol. Nilai rata-rata pada kelas eksperimen 73.10 sedangkan pada kelas kontrol 60.71 dengan selisih 12.63. Nilai maksimum pada kedua kelas berada pada kategori tinggi, yakni 92.86 pada kelas eksperimen dan 85.71 pada kelas kontrol. Skor kemampuan komunikasi matematis terendah terdapat di kelas kontrol, yakni 42.86. Sementara itu, bila dilihat dari standar deviasi nilai pada kelas kontrol lebih menyebar dibandingkan dengan kelas eksperimen.

Data hasil posttest pada kedua kelas kemudian diuji normalitas dan homogenitasnya sebagai uji prasyarat analisis. Uji normalitas data menggunakan rumus chi kuadrat, dengan kriteria pengujian sebagai berikut: Apabila $\chi_{\text {hitung }}^{2} \leq \chi_{\text {tabel }}^{2}$ maka data berdistribusi normal, sebaliknya apabila $\chi_{\text {hitung }}^{2}>$ $\chi_{\text {tabel }}^{2}$ maka data tidak berdistribusi normal.

Tabel 3.

Uji Normalitas Data

\begin{tabular}{cll|}
\hline & Eksp. & Kontrol \\
\hline $\mathrm{A}$ & $5 \%$ & \\
\hline$d_{k}$ & 3 & 3 \\
\hline$\chi_{\text {hitung }}^{2}$ & 2.4428 & 4.877 \\
\hline$\chi_{\text {tabel }}^{2}$ & 7.815 & 7.815 \\
\hline Kesimpulan & Normal & Normal
\end{tabular}

Pada kelas eksperimen diperoleh $\chi_{\text {hitung }}^{2}=2.4428$ sedangkan $\chi_{\text {tabel }}^{2}$ dengan $\alpha=5 \%$ dan $d_{k}=3$ adalah 7.815. Sementara itu, pada kelas kontrol diperoleh $\chi_{\text {hitung }}^{2}=4.877$ sedangkan $\chi_{\text {tabel }}^{2}$ dengan $\alpha=5 \%$ dan $d_{k}=3$ adalah
7.815. Dengan demikian $\chi_{\text {hitung }}^{2}<\chi_{\text {tabel }}^{2}$ sehingga data pada masing-masing kelas berdistribusi normal.

Sementara itu uji homogenitas data menggunakan uji Fisher dengan kriteria pengujian sebagai berikut: jika nilai $F_{\text {hitung }} \leq$

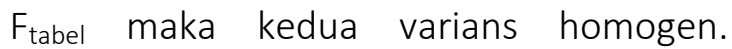
Sebaliknya jika nilai $F_{\text {hitung }}>F_{\text {tabel }}$ maka kedua varians tersebut tidak homogen. Ringkasan uji homogenitas disajikan dalam tabel berikut:

Tabel 4.

Ringkasan Uji Homogenitas Data

\begin{tabular}{|lll|}
\hline & Eksp. & Kontrol \\
\hline Varians & 115.03 & 143.89 \\
\hline$F_{\text {hitung }}$ & 1.2509 & \\
\hline$d_{b}$ & 29 & 28 \\
\hline$F_{\text {tabel }}$ & 1.8677 & \\
\hline Kesimpulan & Homogen & \\
\hline
\end{tabular}

Berdasarkan tabel 6 diperoleh $F_{\text {hitung }}=1.2509$ sedangkan $F_{\text {tabel }}=$ 1.8677. Dengan demikian $F_{\text {hitung }}<F_{\text {tabel }}$ yakni $\quad 1.509<1.8677 \quad$ sehingga disimpulkan bahwa kedua varians homogen.

Karena asumsi normalitas dan homogenitas data terpenuhi, maka uji hipotesis data posttest menggunakan uji t. Hasil uji hipotesis disajikan dalam tabel berikut:

Tabel 5

Uji Hipotesis

\begin{tabular}{llll}
\hline Kelas & $\boldsymbol{t}_{\text {hitung }}$ & $\boldsymbol{t}_{\text {tabel }}$ & Kesimpulan \\
\hline Eksp. & 4.266 & 1.672 & $\begin{array}{l}\mathrm{H}_{0} \text { ditolak, } \mathrm{H}_{1} \\
\text { diterima }\end{array}$ \\
\hline Kontrol & & & \\
\hline
\end{tabular}

Berdasarkan uji hipotesis diperoleh $t_{\text {hitung }}>t_{\text {tabel }} \quad$ yakni $\quad 4.266>1.672$. 
Dengan demikian dapat disimpulkan bahwa kemampuan komunikasi matematis siswa yang menggunakan model pembelajaran kooperatif tipe NHT lebih tinggi daripada kemampuan komunikasi matematis siswa yang menggunakan model pembelajaran langsung pada siswa kelas X SMK Santo Aloisius Ruteng tahun ajaran 2017/2018.

Hal ini dapat terjadi karena dalam model pembelajaran kooperatif tipe NHT, siswa lebih berperan aktif dalam proses pembelajaran sementara guru berperan sebagai fasilitator diskusi. Menurut Isjoni (Pratiwi, 2010: 29) dalam pembelajaran kooperatif, peserta didik terlibat aktif pada proses pembelajaran sehingga memberikan dampak positif terhadap kualitas interaksi dan komunikasi yang berkualitas. Melalui kegiatan diskusi kelompok, setiap siswa mengkomunikasikan ide matematisnya secara lisan kemudian hasil diskusi tersebut dituangkan secara tertulis dalam lembar kerja kelompok. Kemudian siswa yang mewakili kelompoknya melaporkan hasil diskusi kepada guru dan temanteman di kelas kemudian ditanggapi oleh siswa dari kelompok lain. Dalam fase ini, interaksi tidak hanya terjadi antar anggota dalam kelompok tetapi juga antar kelompok sehingga menunjang aspek komunikasi matematis siswa. Ini sejalan dengan pendapat Aulia (2016: 48) bahwa interaksi yang baik dalam kelompok dapat menumbuhkembangkan sikap positif terhadap pelajaran matematika sehingga dapat meningkatkan kemampuan komunikasi matematika. Sementara itu dalam model pembelajaran langsung guru lebih dominan dalam proses pembelajaran. Siswa menerima semua informasi dari guru dan tidak mendapatkan kesempatan untuk menjadi pusat dalam pembelajaran. Hal ini berdampak pada kurang aktifnya siswa selama pembelajaran berlangsung. Siswa hanya menerima apa yang disampaikan oleh guru tanpa diberi ruang khusus untuk mendiskusikan sendiri materi yang dipelajari sehingga kurang menunjang kemampuan komunikasi matematisnya.

\section{Penutup}

Berdasarkan hasil posttest pada kelas eksperimen diperoleh nilai tertingginya 92.86 dan nilai terendah 53.57 dengan rata-rata 73.10 sedangkan pada kelas kontrol diperoleh nilai tertinggi 85.71 dan nilai terendah 42.86 dengan rata-rata 60.47. Nilai rata-rata kelas eksperimen lebih tinggi dibandingkan dengan kontrol dengan selisih 12.63. Demikian pula hasil uji $\mathrm{t}$ pada kedua kelompok diperoleh $t_{\text {hitung }}>t_{\text {tabel }}$ yakni $4.266>1.672$. Dengan demikian dapat disimpulkan bahwa kemampuan komunikasi matematis siswa yang diajarkan dengan menerapkan model pembelajaran kooperatif tipe NHT lebih tinggi dibandingkan dengan kemampuan komunikasi matematis siswa yang diajarkan dengan model pembelajaran langsung. 


\section{UCAPAN TERIMA KASIH}

Penulis mengucapkan terima kasih kepada Program Studi Pendidikan Matematika STKIP Santu Paulus Ruteng yang berkenan mendukung terlaksananya penelitian ini. Terima kasih pula kepada kepala sekolah dan guru matematika kelas kelas X SMK Santo Aloisius Ruteng yang telah memberi izin untuk pelaksanaan penelitian ini baik untuk penggunaan ruang kelas, waktu, maupun tenaga sampai terselesainya penelitian ini. Penulis juga mengucapkan terima kasih kepada Bapak Rully C.I. Prahmana yang telah memberi banyak masukan dalam penulisan artikel ilmiah.

\section{DAfTAR PUSTAKa}

Alamiah, U. S., \& Afriansyah, E. A. (2018). Perbandingan Kemampuan

Komunikasi Matematis Siswa Antara yang Mendapatkan Model Pembelajaran Problem Based Learning dengan Pendekatan Realistic Mathematics Education dan OpenEnded. Mosharafa: Jurnal Pendidikan Matematika, 6(2), 207-216.

Aulia, A. A. (2016). Pembelajaran Kooperatif Tipe Jigsaw untuk Membangun Pemahaman Fungsi Komposisi dan Fungsi Invers pada Siswa Kelas XI IPA 1 SMA Negeri 1 Bolo Bima. DISERTASI dan TESIS

Departemen Pendidikan Nasional. 2006. Peraturan Menteri Pendidikan Nasional No 22 Tahun 2006 tentang

Sistem Pendidikan Nasional. Jakarta: Depdiknas

Fathani, A. H. (2009). Matematika Hakikat dan Logika. Yogyakarta: Ar-Ruzz Media.

Husna, M., \& Fatimah, S. (2013). Peningkatan kemampuan pemecahan masalah dan Komunikasi matematis siswa Sekolah Menengah Pertama melalui model pembelajaran kooperatif tipe Think-pair-share (TPS). Jurnal Peluang, 1(2), 81-92.2

Luritawaty, I. P. (2016). Upaya Meningkatkan Kemampuan Komunikasi Matematis melalui Metode Diskusi Berbantuan Microsoft Office Excel. Mosharafa: Jurnal Pendidikan Matematika,5(3), 213222.

Makur, A., Prahmana, R., \& Gunur, B. (2018). Kemampuan Berpikir Tingkat Tinggi, Peserta OSK Matematika Tingkat SD, dan Strategi Think, Talk, and Write. Jurnal Pendidikan Matematika, 12(2). doi:https://doi.org/10.22342/jpm.12. 2.5677.\%p

Nendi, F., Mandur, K., \& Makur, A. P. (2018). Pengembangan Instrumen Penilaian Kemampuan Koneksi Matematis Dalam Konsep-Konsep Matematika SMP. Jurnal Pendidikan dan Kebudayaan Missio, 9(2), 165173.

Pantaleon, K. V. \& Emer, E. (2011). Penggunaan Alat Peraga Melalui Pembelajaran Tutor Teman Sebaya dalam Pembelajaran Matematika. 
Jurnal Pendidikan dan Kebudayaan Missio, 3(1), 53-63.

Shoimin, A. (68). Model Pembelajaran Inovatif dalam Kurikulum 2013.

Suryadi, D. (2007). Pendidikan Matematika. dalam IImu dan Aplikasi Pendidikan.

Tamur, M

(2012). Pembelajaran

Kooperatif Tipe STAD Berbasis

Etnomatematika sebagai Upaya

Meningkatkan

Kemampuan

Pemahaman dan Komunikasi

Matematis

Mahasiswa

PGSD (Doctoral dissertation, Tesis SPS

UPI. Bandung: Tidak diterbitkan).

$\begin{array}{lll}\text { Pratiwi, } & \text { R. (2010). Penerapan }\end{array}$

Pembelajaran Kooperatif Tipe

Numbered Head Together (NHT)

Untuk Meningkatkan Kemampuan

Komunikasi Matematika Peserta Didik

Kelas VIII SMPN 2 TAMBANG

KABUPATEN KAMPAR (Doctoral

dissertation, Universitas Islam Negeri

Sultan Syarif Kasim Riau).

Sritresna, T. (2017). Meningkatkan

Kemampuan Komunikasi Matematis dan Self-Confidence Siswa melalui Model Pembelajaran Cycle

7E. Mosharafa: Jurnal Pendidikan Matematika, 6(3), 419-430.
Santu Paulus Ruteng lulus tahun 2018. Penulis tertarik dalam pendidikan matematika.

\section{Alberta Parinters Makur, S.Si, M.Pd.}

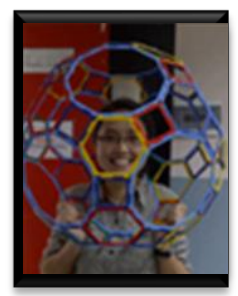

Lahir di Ende, 9 Mei 1988. Staf pengajar di Program Studi Pendidikan Matematika STKIP Santu Paulus Ruteng. Studi S1 Matematika Universitas Indonesia, Depok, lulus tahun 2009 dan S2 Pendidikan Matematika Universitas Negeri Jakarta, lulus tahun 2014. Karir di bidang pekerjaan, Januari 2010 dengan bekerja sebagai Analis Data di SPSS Indonesia. Pada Oktober 2010 penulis bergabung menjadi staf pengajar Matematika di STKIP Surya hingga Oktober 2014. Penulis tertarik dalam olimpiade matematika, etnomatematika, dan matematika GASING.

Apolonia H. Ramda, M.Pd.

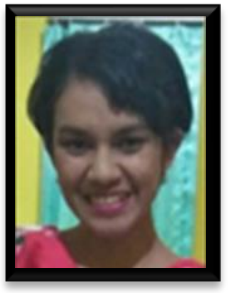

Lahir di Ruteng, 9 Februari 1990. Penulis mengambil jurusan Matematika di Universitas Udayana Bali sejak Agustus 2008 dan meraih gelar sarjana pada Mei 2012. Peneliti melanjutkan pendidikan di Sekolah Pascasarjana UNY pada tahun 2014 dan dan memperoleh gelar Magister Pendidikan (M.Pd) di Universitas Negeri Yogyakarta pada September 2016. Karir di bidang pekerjaan, penulis mulai dari September 2012 bekerja sebagai staf pengajar di STKIP Santu Paulus Ruteng pada Program Studi Pendidikan Matematika hingga sekarang ini. Penulis tertarik dalam pengembangan media pembelajaran matematika.

\section{Riwayat Hidup PENULIS}

Deutelina S. Lagur, S.Pd.

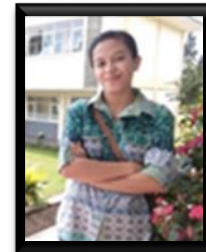

Lahir di Ruteng, 16 Maret 1996. Mahasiswa di Program Studi Pendidikan Matematika STKIP Santu Paulus Ruteng. Studi S1 Program Studi Pendidikan Matematika STKIP 
This page is intentionally left blank 